\title{
Identity quest under the pen of Victor Hugo and Ismail Kadaré
}

\author{
Valbona Gashi-Berisha - Bujar Berisha
}

DOI: 10.18355/XL.2019.12.02.05

\begin{abstract}
What is an individual? Where does his identity lie? All novels are looking for an answer to this question. Indeed, by what does a self-define it-self?
\end{abstract}

Milan Kundera

The need to know oneself, to assert one's identity, belongs to each individual, each community and each culture. Identity can be considered as the temporary result of a cultural process in constant transformation.

The study focuses on two literary works, Les Misérables by Victor Hugo and Avril Brisé by Ismail Kadaré, with the common theme of the quest for identity. The particularity of the character of Victor Hugo lies in the quest for his identity. Jean Valjean is in the center of Les Misérables and becomes a testimony to the power of the quest for identity. Hardened by prison and saved by the kindness of Mr. Myriel, Valjean is a symbol of the courage to be oneself and to assert oneself in front of others with an ability to change. After accepting to change the identity in all forms, the character accepts the world in which he lives, since, in the end, he occupies a place in society: Mayor of Montreuil and father of the little Cosette.

Ismail Kadare marks the opening of Albanian literature on the world, highlighting the Albanian identity and portraying in the image of each character the mark of the honor of the name and the family. In his novel, Avril Brisé talks about George, a young man, whom the company guides him and the first characteristic of the character is to wander on the roads of bessa rather than to act there.; In this quest, he knows in advance that his goal is only a desire, for the identity never allowed to identify oneself, to possess oneself fully; it belongs to Kanun, regulating the whole life and destiny of man.

The issue of the quest for identity that runs through these two works will be analyzed, through the relationship between society and individual.

Key words: identity, quest, character, society, family

\section{Introduction}

In Les Miserables, Hugo retraces the social impact of numerous revolutions that took place during nineteenth-century France, giving us an idea of the perpetual uncertainty that political events impose on everyday life. In the work of Kadare, the two antagonistic forces - modernity, on the one hand, and tradition, on the other - project a future identity while emphasizing the past. If Kadare dives into tradition, it is to show the remains left of the Ottoman Empire occupations, which lead him to a quest for the identity of his nation. The historical events, the society, and the family environment constitute the raw material of his works. His character in Broken April, Gjorg is facing the innumerable injustices generated by social and family laws that in truth deprive him of the most basic right, the right to live.

Kadare's character reflects a rather shocking reality, "what was happening in Albania that in a dictatorship the most titanic battle is not the fight against the dissidents, but in a more mythical and general way, it is the fight against human life."(Kadare, 1991: 107)

In almost all novels, the identity of a character is often composed of two poles: his personality, and his physique. In Les Miserables, the reader finds a fairly detailed description of Jean Valjean's character, something that Gjorg's character lacks, but

XLinguae, Volume 12, Issue 2, April 2019, ISSN 1337-8384, eISSN 2453-711X 
what is important is the psychological identity. Our characters, Jean Valjean and Gjorg both suffer from a vague, lost identity and will never manage to regain a feeling of certitude concerning their identity. Their actions, their desires, their very personalities can be determined by something which is in them, but which eludes them: their unconscious. Sigmund Freud discovered the unconscious in 1900 (The Interpretation of dreams marks the birth of psychoanalysis at the beginning of the twentieth century): man is no longer one; he is divided, (conscious/unconscious).

\section{The determining family of identity}

The name is what symbolizes a character to the highest degree: "A name is a me" says Jean Valjean at the beginning of his itinerary. Jean Valjean is, at the beginning of the book, an illiterate pruner who lost his parents too early. He is described as a "sturdy man of medium size". (Hugo, 1963: 70). Victor Hugo makes a subjective portrait of Jean, in fact, he gives him the image of a man that life did not help, which accumulates misfortunes (his social status, the death of his parents and soon after of his brother in law) and yet, faced with this tragic destiny, this character reacts positively. Jean Valjean was loved since childhood; if not, how would he have spontaneously taken care of his sister and her children when she found herself a widow. It is also deduced that he had rather good relations with his father since they gave space to a positive identification; Jean Valjean is called like his father, Jean Valjean or Valjean, a contraction of "Voilà Jean", and he has also become a pruner like him.

In Broken April, Kadare gives us a relatively faithful picture of the tradition of revenge suffered by his character in a society still ruled by the laws of Kanun. Gjorg sees himself under the yoke of his family who determines his identity. He "was the last male in the family after his father". (Kadare, 1982: 53). The identification of Gjorg is based on his status as an avenger:

He had the impression that his name had come out of his body, his chest and his skin, to spread cruelly outside. It was the first time he felt such a sensation. Gjorg of Berisha. He repeated in himself the cry of the pitiless herald. He was twenty-six years old, and for the first time, his name penetrated the foundations of life. (Ibid.,: 12-13).

At first, Gjorg represents only a foggy identity, born of a generation in vendetta; he is without landmarks. He gets caught up only in the circle of vengeance and his laws. The laws of Kanun determine his identity and prevent him from owning his fate himself.

At the exit of the prison, the identity of Jean Valjean is marked with a yellow passport which will determine his status of a discharged convict. From now on, his identity is forever bound to his fault:

Here is my passport. Yellow, as you can see. This serves to expel me from every place where I go. Will you read it? I know how to read. I learned at the galleys. There is a school for those who chose to learn. Here is what they put on the passport. Jean Valjean, discharged convict [...] has been nineteen years in the galleys. Five years for burglary and housebreaking. Fourteen years for attempting to escape on four occasions. He is a very dangerous man.”(Hugo, 1998, [1862]: 118).

The transition from the status of the prisoner into a free man marks the point where Jean Valjean becomes conscious. This new identity will follow him until the end of his life. While he arrives at Digne in search for a place to sleep for the night, his former prisoner status closes all doors except that of Bishop Myriel, the bishop of the village, who offers him shelter and cover. However, Jean Valjean fled into the night and stole silver and two candelabra. He is taken back by the police and brought in front of the clergyman. The latter forgives his misdeed and commits him to do good. After the last offense, he follows the advice of the bishop. His meeting with the 
Bishop of Digne comes to make him aware of the transformation that the misery has done to him: he is now committed to doing only good. A long operation of redemption marked with sacrifices begins then for the former convict.

\section{Loss of identity by society}

In Les Miserables, Victor Hugo emphasizes the dehumanization engendered by the prison where the convicts come to lose all identity in the literal sense of the term. He described Jean Valjean when he joined the prison of Toulon: "All that had constituted his life, even to his name, was effaced: he was no longer even Jean Valjean,; he was number 24601. "(Hugo, 1963: 98). Having tried to escape four times, Valjean must remain in the galleys for nineteen years. He learns to read and write, but because of his long condemnation, he becomes hardened. "He had entered the prison sobbing and shuddering, he emerged impassively; he had entered desperate; he emerged gloomily "(Ibid.,: 100). For many years in the galleys, he did not even have his name; he got only number 24601 . Out of the galleys, he remained a criminal for everyone even if he tried to be polite with everyone. On his release, Jean Valjean resembles a wild animal. His yellow passport of former convict makes him a reprobate for life in the eyes of the society: "he very speedily perceived what sort of liberty it is to which a yellow passport is provided...liberation is not deliverance. One gets free from the galleys, but not from the sentence " (Ibid.,: 110).

Jean Valjean feels weakened, rejected by everyone, even by the animals that pass by, like when he enters the niche of a dog and is rejected. So he feels inferior even to the dog "I'm not even a dog! " (Ibid.,: 79), the prison has dehumanized him. When Jean Valjean arrives at Montreuil-sur-Mer, he is only a stranger. He does not have a name. He is called "a man", "an unknown", "the author of this process", "he". His name is known only very late because as long as he has not made a fortune, this man is only a stranger to the city. Moreover, it is by taking the name of Mr. Madeleine that this character is really born.

If for Jean Valjean everything is difficult, for Gjorg everything is a disorder; but it is a rhetorical disorder. He must avenge his brother in order to accomplish what he considers a duty. The essential thing, perhaps, is not to efface the shame that haunts the Berisha family but to provide proof of his manhood and honor. About this he says:

Two fingers of honor on the forehead ... [and] he touched his forehead with his hand as if to find the exact spot where the honor could be ... Honor has its seat in the middle of the forehead because that is where the bullet must reach the other's head. (Kadare, 1982: 52).

The frequent metonymy of the "forehead" represents the image par excellence of this world of honor. For Kadare, the forehead also has the role of signifying pride. Gjorg's quest, in which inevitable death intersects with incarnated life, is confronted with the harsh reality that sinks into the unconsciousness and the loss of identity. He is confronted with the destiny over which he has no choice since the Kanun determines it. At times his mind went astray, sought to snatch fragments of stories to stick to his own life, or, on the contrary, to attach pieces of his life to the stories of others, but this college was not always easy to put together. (Ibid., P.180-181).

It is because death exists in him and that he lives every moment of it, even its smallest details, that Gjorg must respect the Kanun, which is "more powerful than it seemed" (Ibid., 29): kill the enemy to wash the shirt, bloody, remained on the earth as a message from the dead. This "frozen blood" in the shirt clearly shows the importance of revenge; it remains the symbol of the insurmountable border between the world of the living and the world of the dead.

\section{New identities}

XLinguae, Volume 12, Issue 2, April 2019, ISSN 1337-8384, eISSN 2453-711X 
We will witness the acquisition of new identities of our two characters in two different societies. For Jean Valjean, there is only the Bishop of Digne who behaves well towards him by having welcomed him into his house. Yet, it is precisely at the bishop's where Jean Valjean, depressed by his hopeless situation, steals silverware. It is then his meeting with the Bishop of Digne that comes to make him aware of the transformation that the misery has caused in him: he is now committed to doing good. When we observe his behavior after this incident, we witness the "obscure progress by which this formidably simple soul is released (...) to enter the humanity". (Lasserre, 2000: 221).

As for Gjorg, he becomes aware of himself by accepting Kanun rules. Kadare gives us a relatively faithful picture of the manners of vengeance that the individual was the victim of in a society still ruled by the laws of Kanun. Kanun, in a way, aims to bring order and peace to the very conscience of even the avenger. The only satisfactory revenge, before the shed blood, is to shed the blood of the criminal. Kadare portrays an unrelenting vendetta of twenty-two tombs on either side, in all forty-four, seventy years of hatred and transversal vengeance that continues as long as the Kanun exists. It plays a significant role in Kadare's work and is "the only important event in the life of the highlanders to which children are invited [to] keep their memories as long as possible". (Broken April: 101)

The character of Gjorg refers to three stages of self-awareness:

- $\quad$ At first, he has but a foggy identity; born of a generation in vendetta, he is without landmarks.

He then perceives himself under the yoke of his family, who determines his identity. The laws of Kanun destroy his identity and prevent him from recovering from himself.

He ends by getting caught up only in the circle of vengeance and its laws. Then he gets the status of avenger and after that of a murderer.

As for Jean Valjean, on his arrival at Bishop Myrriel's, he is a man that has been destroyed by society. The bishop's kindness makes him aware that he also is capable of committing good deeds for the world around him, which he proves after in Montreuil-sur-Mer. He settles in Montreuil-sur-Mer under a false name with the desire to escape his old identity and to rebuild his existence. Indeed, Jean Valjean becomes Monsieur Madeleine, a discreet and taciturn industrialist who fights poverty by creating numerous institutions of public utility and who is honored by everyone:

Happy in feeling his conscience saddened by the past and the first half of his existence belied by the last, he lived in peace, reassured and hopeful, having henceforth only two thoughts,-to conceal his name and to sanctify his life; to escape men and to return to God.”(Hugo, 1998: 322)

His identity was well hidden and his past far away until the moment when he decides to save a man, stuck under his cart. Among the people who witnessed the accident of Fauchelevent was Inspector Javert, a new police officer in Montreuil-sur-Mer, who very clearly pronounced: "Monsieur Madeleine, I have never known but one man capable of doing what you ask.(...) He was a convict." (Hugo, 1963: 191). By saying this, he thought of no one else but Jean Valjean, whose physical strength he had observed at the galleys of Toulon.

Javert never forgot this event, and since that time his eyes were fixed on Monsieur Madeleine. Six weeks after, Inspector Javert came to announce to Monsieur Madeleine that "the real Jean Valjean has been found".(Ibid, P. 224)

Hearing his real name, which should have long existed, was a shock so great to him that he was not sure whether it was a nightmare or reality."Am I dreaming?" - "What 
was I just told?" - "Is it true that I just saw this Javert and he has spoken thus to me?"(Ibid.,p. 241).

Jean Valjean starts wondering if he must confess his true identity. It would be really easy to do nothing and let things take their course, to remain Madeleine, Monsieur, the Mayor of Montreuil-sur-Mer, to forget Jean Valjean, get rid of Javert and close the doors of his past forever. "I am Madeleine, and Madeleine I remain. Woe to the man who is Jean Valjean! I am no longer he; I do not know that man; I no longer know anything if it turns out that someone is Jean Valjean at the present moment;(...)". (Ibid., p. 251)

After a long night of hesitation (a storm inside his head), Monsieur Madeleine decided to denounce himself in order to prevent poor Champmathieu, a bit simple-minded, from being sentenced in his place. From that very moment, he was another man. What the bishop wanted him to turn to, he had become. "It was more than a transformation; it was a transfiguration". Monsieur Madeleine, who does not wish to have an innocent person condemned in his place, goes to court and when he sees the accused, he can no longer hide his identity.

He does not hesitate to clear Champmathieu of the accusations, even if he knows that his freedom depends on it. To prove his identity, he reveals the wilt " 24601 " inscribed on his chest. He manages to escape before they can arrest him.

Being able to escape from Javert at the end of Volume I, Jean Valjean is caught in Paris. He is sent back to the galleys. "JeanValjean changed his number in the galleys. He was called 9430.”(Ibid., 385).

In his new role, Gjorg, a murderer, must adapt to his new life. He sees himself then compared to Hamlet, and carries the mortal seal around the arm, in the form of a black ribbon, which designates him in the eyes of the community as both a murderer and a future victim. Any resumption of blood was subject to a precise ritual: preceded by an announcement and a truce of 24 hours, the murderer was to participate in the funeral and the funeral meal in honor of the victim, the vendetta (gjakmarrja) could be delayed for a new 30-day truce leaving friends time to begin negotiations with the victim's family.

After Gjorg has taken revenge, the Kryeqyqe family grants the bessa "that sublime force, capable of imposing the laws of death." (Kadare, 1986: 149). This short truce of twenty-four hours is granted to Gjorg and his family, just to attend the funeral ceremonies. The funeral, the mortuary meal, the twenty-four-hour truce are conducted according to custom, like the murder itself, which was conducted according to the tradition of the country. Gjorg could not violate this age-old custom. He had behaved with dignity during the burial of his enemy as during the mortuary meal. And Gjorg thought of his own funeral meal, "he felt that henceforth the whole life of successive generations of their two families would be an endless mortuary meal, offered one after another for each of the two families". (Kadare, 1982: 19).

A few hours after the funeral of the Kryeqyqe, the short truce expires for Gjorg. He becomes the acting symbol of the victim to the unfulfilled fate as long as he is not avenged. It is the man facing the destiny, the circumstances of revenge, but also of his life. And just before the expiration of the small bessa, Gjorg is granted the great bessa, a truce of thirty days according to the rules of Kanun. The agreement is concluded on the seventeenth of March, so for Gjorg a free life of thirty days, still under the bessa, thirty days without danger, from the mid-March, "half-smiling"; "half-frozen", to mid-April, "an April death"; "an April unfinished".

\section{The wandering characters}

The common point between Jean Valjean and Gjorg is the wandering. Hugo's character wanders through the labyrinth of Paris while Kadare's character "chose" to wander in spite of himself on the plateau of the high mountains. After having once again escaped Javert, Jean Valjean raises Cosette as his own daughter, while hiding in 
the convent of the little Picpus, where he finds Father Fauchelevent to whom he saved the life in Montreuil-sur-Mer. At the convent, he is officially admitted as a gardener's helper, presenting himself as the brother of old Fauchelevent. Jean Valjean has a new identity; from then he would be called Father Fauchelevent. Fearing that Cosette could not live happily in the convent, he bought the house on Rue Plumet. Fearing that he would be discovered, he rented two other apartments at the same time: one in Rue de l' Ouest, the other in the Rue de l'Homme Arme.

Having become the old man with white hair who accompanies Cosette during all of her promenades, the friends of Marius designate him under the name of Monsieur Leblanc. Once again, the incognito existence of Jean Valjean is threatened, once again he must move, leave the house on the Rue de l'Ouest where he had taken refuge, leave without leaving any traces behind. We will learn later that he [snuggled] rue Plumet while renting "two other apartments in Paris". (Hugo, 1963: 407).

Finally, there is not so much difference between the one that Marius calls Mr. Leblanc and the industrialist Mr. Madeleine. Again, Jean Valjean wears the mask: "he hid his name, he hid his identity, he hid his age, he hid everything ... Resembling the first comer who pays his contributions, that was all his ambition." (Ibid., 409).

As for the fate of Gjorg, it is engraved at the bottom of the stones that lie beneath the Kulla of Orosh. His sense of honesty is only an internal debate that cannot escape the laws of Kanun. It is there that Gjorg will pay the blood tribute to be able to wait for his death with dignity. This Kulla, nourished with the blood of murders, is the equivalent of Aeschylus' Erinyes. It is a mysterious guardian of Kanun, forming together an untouchable law. Gjorg is a murderer, but it was the Kanun who drove him to death.

Kanun, like the Erinyes, urges men to commit culpable acts and punishes them for doing so, even if they do everything to avoid them. Thus, men are subject to the laws of Kanun, and the guilty cannot escape the punishment that awaits him. Moreover, this Kanun, who encourages the vendetta in the name of honor, keeps on watching for the slightest act of the avenger. "Thus, from hour to hour and from day to day, his mind broke with the reality of things, and his journey started to resemble more like a wander in a dream." (Kadare, 1982: 183).

The fate of Gjorg is marked by the "black ribbon", which awaited him perhaps since his birth. It is this black ribbon on the sleeve, indicating that he asked for death or was asked by her, who will follow Gjorg night and day. He wears on him the sign of death, like all men in vendetta who "roam the roads with this black ribbon on their sleeves like ghosts in the fog." (Ibid., P.79).

He must learn to chase the anguish of life, which could only be ephemeral, in this "zone where the rules of death pass before that of life." (Ibid., P.78).

\section{The Last Identity}

While Gjorg wandered in the death zone, Jean Valjean uses false names to hide his past and live his alter ego more profoundly. His false identities are a means of survival and a way to reveal himself for what he really is. However, the identity of Jean Valjean proves to be more and more solid through all these vicissitudes of each transformation. The first thing he does after Cosette's wedding is to change his false name in front of his new family.

The identity quest of Jean Valjean is also acknowledged when he saves Marius. This stage of his quest is decisive because it puts an end to the mask games, to the temptation of disguise, and also to internal conflicts. Without a doubt for the first time, Jean Valjean agrees to be all that he is; that is why he identifies himself while leaving through the sewer, and Javert had not recognized him. To name oneself bin front of Javert is to accept one's destiny, perhaps even to provoke it. Jean Valjean attains lucidity by noting that the name is a self and that it is useless to think of accessing a being by hiding it. 
When Marius finally recovered six months after being wounded on the barricades, his grandfather allowed him to marry Cosette, whose "father" was to give a very large dowry of 600,000 francs. Then these two young people found their intimacy and discover the great happiness of it while being watched by the angels. Back home, Jean Valjean spends the night crying; he is again the prey of a cruel internal debate: must he reveal to Marius, who knows him under the name of Fauchelevent, his true identity? After the marriage of Cosette, Jean Valjean decided to tell Marius the truth about his life, but the only truth he can see is that of the former convict. (Hugo, 1963: 431).

The next day, he confessed to the young man that he is a former convict and that Cosette is not his daughter. Marius, ignoring the real personality of the convict, remembers then all the curious behaviors of Jean Valjean and decides that the old man must distance from his visits to Colette, and he will never see her again.

Because of Jean Valjean's confession, the positions in the family changed completely. Marius, who had only been a poor student, became Baron Pontmercy, while the honorable M. Fauchelevent, Cosette's father, was no more than an old galley slipper having nothing in common with her. Although Valjean knew that this would happen, he did confess his identity, because he felt that his "son-in-law" had the right to know him. However, nobody except himself took for real the confession that he made.

Moreover, he calls Cosette no other than "Madame Pontmercy" and asks her to call him "Monsieur Jean" instead of "father". By consulting the newspapers, Marius discovers the infinite goodness of Jean Valjean, while Thenardier constantly persuades him that Valjean is still a thief and a murderer. He tells her that he saw him during the attempted revolution in a sewer with a corpse on his shoulders and that it was undoubtedly a very rich man that Valjean had killed and stolen. To justify his claims, Thenardier shows a piece of clothing that belonged to this murdered young man. For Marius, it is the last fact that made him discover the true character of "his father-in-law". And then, without saying a word, Valjean abandoned Cosette so that she would have nothing in common with a former convict. But for Marius, "the convict was transfigured into a saint." (Ibid., 492).

Throughout the novel, Jean Valjean changes his face, changes his identity and finally ends his life under his real name that he had inherited from his father "Jean Valjean". While Jean Valjean uses false identities as a means of survival, for Gjorg, the passage from life to death, from unconsciousness to consciousness, is described through a cruel reality: "We entered the kingdom of death like Ulysses, with the only difference that Ulysses had to descent in order to reach it, while we have to go up."(Kadare, 1982: 79)

Gjorg, when entering the world of the dead, is "the only man among all who knows he will die. Doubtlessly only his heart shudders, and the death of Zef of Kryeqyqe is already his death, and his burial already his burial ". (Gashi, 2000). He confronts his fate without trembling since everything dies, so why would it matter! It is because he is a living being that he hears the hammered steps of death approaching. For Gjorg everything is decided in advance, the time of his death has become an expected moment. He finds his death at nightfall so that the vengeance can begin the very next morning. All the characters of Kadare are caught in a cycle of revenge, and we can say that his novel has neither a beginning nor an end. Broken April begins with a murder and ends with a murder, but it is death that dominates throughout the work. "In the end, the dimension of death conferred something eternal to the lives of these men." (Ibid., 81).

It is because Gjorg while still alive is in his quest towards death that Diane, on honeymoon, is looking for "the pale highlander", "the shadow of the living". Then, lead by desire and the lack of sources of life, Diane descends into the kingdom of Hade:

XLinguae, Volume 12, Issue 2, April 2019, ISSN 1337-8384, eISSN 2453-711X 
It was like the gates of hell. Suddenly, with unbearable intensity, the vision of the man who had passed through this hell came back to her. She called for Gjorg silently, stirring her icy dreams. He wandered through these inaccessible paths, carrying messages from the dead in his hands, in his sleeves, in his wings. It must have been a demi-god to stand up to this darkness and chaos of creation. (Ibid., P.14)

Gjorg's quest for identity in the world of the living is pursued by the specter of the blood on his brother's shirt that was turning yellow, which reminds him of the duty of vengeance, the wish of his father, and that of the society for human equilibrium. This quest represents the journey to the Kulla of Orosh in order to pay "the tax on blood", the thirty days of respites that are inscribed and claim the passage from life to death, from the unconsciousness to the consciousness, from the truth in our world where a cruel reality reigns. I would like to end this article with a quotation from Kadare on this shocking reality: "... that in a dictatorship, the most titanic battle is not the fight against the dissidents, but in a more mythical and general way, it is the fight against human life". (Kadare, 1991: 107).

\section{Conclusion}

So, a genius like Hugo and Kadare, rarely sketches this delicately the traces of tyranny in the shivering souls that torment our two heroes; yet in the hell of their both of their lives there is an angel: Jean Valjean, the former convict, is transfigured into a saint and Gjorg, a murderer is transfigured into a demi-god.

With each transformation, Jean Valjean gains experience and becomes wiser and sharpens his mind. Throughout the whole history, Jean Valjean will remain humble and will keep a modest way of living even when he has the means to do differently, like when he is Monsieur Madeleine and still lives in a place without any valuable object. He also remains a good man: He revives the economy of Montreuil-sur-Mer, he saves Cosette from the hands of Thenadiers, he is honest in the case Champmathieu by denouncing himself, he saves Javert during the Uprising.

Hugo wanted to show that a man can change and that a former convict can become a respectable and respected man. Finally, it is thanks to others that the character of the hero got gradually built, thanks to Bishop Myriel who gave him back his selfconfidence, to Cosette who taught him to love, and to Fantine.

Jean Valjean and Gjorg have similarities that are sometimes identical, but in their essence the two are different. As identical points are the cultural and traditional aspects that the society imposes them to live with new identities and the different points are the new identities that they receive, Jean Valjean transforms and changes at every opportunity that he gets, while Gjorg lives and deep inside him is aware of these imposed identities.

\section{Bibliographic references}

GJEÇOVI, SH. 1993. Kanuni i Lekë Dukagjinit, Tiranë: Albinform, ISBN-13: 9781499126006.

GASHI, V. 2000. Perspectives comparatistes à partir de l'œuvre de Sami Frashëri, étude du thème de la vendetta et de la bessa par rapport à d'autres écrivains européens, ANRT, Lille. ISBN : 2-7295-6364-4.

HUGO, V. 1963. Les Misérables. Paris : Gallimard. ISBN: 9782013214698

HUGO, V. 1998, [1862]. Les Misérables. Tome 1, Paris, Le Livre de poche. ISBN : 978-2253096344.

KADARE, I. 1982. Avril brisé, traduit de l'albanais par Alexandre Zotos, Paris : Fayard. ISBN: 9782213011097.

KADARE, I. 1986. Qui a ramené Doruntine? Traduit de l'albanais par Alexandre Zotos, Paris : Fayard. ISBN : 9782213017082. 
KADARE, I. 1991. Entretiens avec Éric Faye, Paris: José Corti. ISBN: 9782714304155.

KUNDERA, M. 1993, Les testaments trahis, Paris, Gallimard, p. 21-22. ISBN : 9782070414345.

LASSERRE, P. 2000. Le romantisme français : essai sur la révolution dans les sentiments et dans les idées au XIXe siècle, Slatkine. EAN : 9782051017121.

STEVENSON, R. L. 1992. Les romans de Victor Hugo, in Essais sur l'art de la fiction, Paris : éd. Payot. ISBN : 2-228-88542-8.

Les Misérables, Victor Hugo, BNF, Gallica, mise en ligne en 21/10/2008

Available online : http://catalogue.bnf.fr/ark:/12148/cb306255232

Words: 5836

Charters : 33707 (18,73 standard pages)

Assoc. prof. dr. Valbona Gashi-Berisha

Department of French Language and literature

Faculty of philology, University " Hasan Prishtina" of Prishtina

10000 Prishtina,

Kosovo

Valbonagashi@uni-pr.edu

Dr. Bujar Berisha

Psychiatry

College of medical sciences

10000 Prishtina,

Kosovo

dr.bujarberisha@gmail.com 